\title{
Occupational hazards in opinions of forestry employees in Poland
}

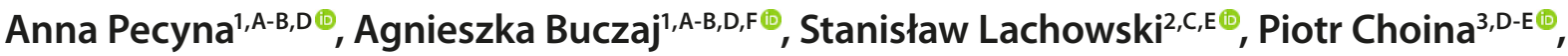 \\ Małgorzata Goździewska ${ }^{3, D-E} \oplus$, Elżbieta Monika Galińska ${ }^{4, D-F} \oplus$ \\ ${ }^{1}$ University of Life Sciences in Lublin, Poland \\ ${ }^{2}$ Maria Curie-Sklodowska University, Lublin, Poland \\ ${ }^{3}$ Department of Medical Anthropology, Institute of Rural Health, Lublin, Poland \\ ${ }^{4}$ Department of Biological Health Hazards and Parasitology, Institute of Rural Health, Lublin, Poland \\ A - Research concept and design, B - Collection and/or assembly of data, C - Data analysis and interpretation, \\ $D$ - Writing the article, E - Critical revision of the article, F - Final approval of article
}

Pecyna A, Buczaj A, Lachowski S, Choina P, Goździewska M, Galińska EM. Occupational hazards in opinions of forestry employees in Poland. Ann Agric Environ Med. 2019; 26(2): 242-248. doi: 10.26444/aaem/106246

\section{Abstract}

Introduction. Work in forestry has been and continues to be considered a very difficult and risky occupation, with constant exposure to certain factors which create risk for employees' health or even life. The objective of the study is recognition of the opinions of forestry workers concerning health risk, and to evaluate which of their selected demographic characteristics are connected with opinions concerning hazards at the workplace.

Materials and method. An author-constructed survey was conducted among 135 forestry employees, containing items concerning primarily hazards occurring at workplaces in forestry. Forestry employees' opinions pertaining to occupational hazards were analyzed from the aspect of independent variables, such as workplace, period of employment, age and education. The significance of the differences in the subgroups distinguished according to the above-mentioned variables, were assessed using the chi-square test.

Results. Forestry employees most often indicated risk related with cold (83.7\%) and hot (77\%) microclimate. A high percentage of respondents (74.1\%) were aware of the presence of biological hazards and risk caused by the possibility of contact with wild animals (55.6\%) at their workplace. In addition, a considerable part of workers reported that the source of risk at their workplace is noise (34.1\%), especially dangerous machinery (26.7\%), dust (18.5\%), chemical substances (15.6\%), and forced body position at work (14.1\%).

Conclusions. Based on the results of the study concerning work safety and occupational hygiene among forestry employees, it was found that they are aware of hazards which may occur at their workplaces. The greatest differences in the perception of hazards were observed according to the type of workplace and period of employment.

Keywords

occupational hazards, forestry, Work Safety and Occupational Hygiene, employees' awareness

\section{INTRODUCTION}

The total area of forests and forested land in the European Union is 161 million hectares, which is $4 \%$ of the forested area worldwide. Timber, as the main forest resource, constitutes in the EU nearly a half of the energy originating from renewable resources. In addition, forests also provide products other than timber, such as: food products (meat, berry fruits and mushrooms), cork, resin, oil, etc. They are also a basis for some services, such as hunting or tourism. Thus, forests are a source of employment, especially in rural areas. According to the data by the European Parliament, approximately 2.6 million people are employed in this sector [1].

In Poland, forests occupy approximately $30 \%$ of the territory of the country and grow over an area of 9,242,400 thousand hectares. These are mainly State forests, of which $80.7 \%$ are managed by a uniform organization - the State Forests National Forest Holding (PGL LP). Within the structure of the State Forests there function 17 Regional Directorates of the State Forests and 430 subordinate forest districts. A

Address for correspondence: Agnieszka Buczaj, University of Life Sciences in Lublin, Poland

E-mail: agnieszka.buczaj@up.lublin.pl

Received: 07.02.2019; accepted: 09.04.2019; first published: 17.04.2019 forest district is the basic organizational unit in the State Forests, and is managed by a forest district manager, who independently carries out forest management based on the forest management plan, and is responsible for the condition of the forest. Forest districts are divided into forest ranger areas, the number and area of which depend, among other things, on the state of dispersion of forests and the amount of economic tasks. At the end of 2017, the State Forests employed nearly 26,000 employees. Of this number, 2,400 (approx. 25\% of the total number of employees) were employed at nonlabourer positions, and 2,200 persons (8\%) were employed at labourer positions. The greatest number, approximately 17,000 (66 \% of the total number of people employed in the State Forests) were Forest Service Employees [2, 3]. To this group belong: forest district manager, assistant forest district manager, supervising engineer, forest ranger, assistant forest ranger and forest guard. The forest district manager, assistant forest district manager, and supervising engineer manage the work of the remaining forestry employees. The forest ranger is appointed to perform technical-economic, protection and administration-office tasks in the entrusted area, and performs these tasks independently, or with the help of subordinated assistant forest rangers. The scope of activities at these positions is very similar, the difference 
being that the assistant forest ranger performs tasks in the field, whereas the forest ranger is additionally occupied with administrative office of the forest ranger area (reporting, stock-taking, settlements, planning of forestry economy on the assigned forest ranger area).

The place of work of the forest ranger is the assigned forest ranger area of the size from 400 to even 3,000 ha. Forest guards are appointed to fight against crime and offences in causing damage to the forest and the protection of nature. In addition, in forestry are employed office workers, clerks, dealing with a specified scope of problems concerning forest economy, and forest service specialists who work both in the office and in the field, occupied with, e.g. forest economy, ecology education of adolescents, or management of ecosystems. At present, the State Forests, while performing tasks associated with running of forest economy, to a great extent, use the private sector where formally there function approx. 672 enterprises, each employing more than 9 workers, while the majority employ more than 49 people [2].

Forestry Services Companies perform many various tasks within the scope of forestry economy on behalf of the State Forests. Lumbermen employed at the Forestry Services Companies are engaged in, among others, cutting, felling, delimbing, and sawing into logs. These activities are associated with high risk of injures. Workers engaged in timber harvesting and extraction are most exposed to accidents at work and to occupational diseases [4].

\section{Hazards in the public sector of forestry}

According to the data by the Statistics Poland in 2018, 2,142 persons were employed in hazardous conditions [2]. Due to the character of performing work, work in forestry belongs to the hazardous occupations. The environment in which forestry employees perform their work creates many and varied hazards induced by the work environment, such as noise, vibration, dust, radiation, cold and hot environment. Additionally, forestry employees are exposed to great physical effort, as well as biological, chemical and mechanical hazards [5].

Many work activities associated with widely understood forest maintenance, such as assessment of the stand, marking trees to be cut, planning of tree care activities, selling of timber, evaluation of the occurrence of risk on the part of pests (setting traps for insects), planning and performance of plantings, assessment of the state of forest roads, counting of animals, and many others, performed mainly by persons employed in the position of a forest ranger, assistant forest ranger and inspector, takes place all year round, directly outdoors in various microclimatic conditions. Work outdoors, exposed to all weather conditions, should be considered as work in a changeable microclimate, according to the season of the year and the prevailing temperatures. Such work may be arduous (e.g. due to rain), but also in hazardous conditions (low temperatures in winter, or very high temperatures in summer which may cause heat stroke). Noise is an important risk factor which occurs primarily during forestry work, especially during the felling of trees. However, it should be noticed that noise exerts an effect not only on the working lumberjacks, but also on other workers who are present in the vicinity of tree felling, e.g. persons who supervise work (forest ranger, assistant forest ranger), those occupied with the cleaning of the area or transport of the obtained timber to the storage place. Noise hinders perception of acoustic signals, the reception of which is the precondition of work safety (e.g. at the work of several work teams in the felling area or at the work of a lumberjack with a helper). Apart from causing occupational disorders (occupational deafness), it may also be the cause of accidents. In addition, noise causes mental function disorders - hinders thinking processes, weakens concentration, and finally favours imprecise performance of activities $[6,7,8,9]$.

The risk of injuries occurring at workplaces in forestry may result from such events as slipping, stumbling or falling [10]. They may occur during the setting of traps for insects or nesting boxes for birds (fall from height), or during the counting of animals, and walking along a specified forest area in order to perform, e.g. a stock survey. Among occupational groups, field workers of forestry administration (forest ranger and assistant forest ranger) are those who most often sustain injuries [10].

Also, long-lasting, forced body posture plays an important role in the work of forestry employees, temporary overloading of the musculoskeletal system due to the necessity of lifting heavy objects or long-lasting walking over a difficult area. Complaints on the part of the musculoskeletal system are enhanced by high energy expenditure and adverse weather conditions [11, 12, 13, 14]. Risk associated with noxiousness of work also occurs while performing administrativeoffice activities. Working at a computer is a source of musculoskeletal complaints resulting from assuming a sitting posture, and improper organization of the workplace [15].

Field workers of the forestry services have constant contact with nature - with plants, animals, and substances produced by them. This results in the occurrence of many biological hazards associated primarily with the possibility of infection with bacteria, viruses, pathogenic fungi, and parasites [16]. Contact with insects, ticks and other animals may be equally perilous, and the substances produced by them: faeces, saliva, blood, venom, are especially dangerous. Also, biological hazards concern the possibility of allergy or poisoning with substances produced by plants or infection with the germs of zoonoses, such as borreliosis (Lyme disease), rabies, tickborne encephalitis and meningitis, or tularemia $[17,18$, 19]. Biological factors occurring in forestry include also the occurrence of allergy of the upper airways as a result of exposure to filamentous fungi, some structures and substances produced by trees (pollens, essential oils, resins), as well as allergens of some caterpillars feeding on trees, or dermatitis as caused by contact with liverworts or lichens $[16,20,21,22]$.

An inseparable hazard at the work of forestry employees are wild animals, which represent a real threat, e.g. during timber extraction, a female animal protecting her young, an animal infected with rabies, a wounded animal, or venomous insects.

The following occupational diseases and accidents in forestry evidence occupational risk in forestry. According to the data by the Statistics Poland, in 2017, in the whole forestry sector (public and private sectors, without institutions employing less than 9 employees), 154 cases of occupational diseases were registered as a result of exposure to primarily biological factors (140 cases of infectious diseases, parasitic diseases or their consequences) [2].

According to the data by the Statistics Poland, in 2017, in the public sector of forestry the number of victims of accidents was 283. Accident risk was most often associated with the 
improper behaviour of an employee [2]. The most dangerous activities were those connected with timber harvesting, performed by private sector enterprises. In the public sector, there dominated accidents defined as those related with 'remaining work activities', i.e. including activities other than those related with the harvesting and transport of timber, Despite the fact that the most dangerous work activities are performed by service companies, an increase has been observed in the severity of accidents in the State Forests [4, $5,10,23]$.

An improvement in work safety may be achieved, among others, by the introduction of technical-organizational changes limiting the effect of hazards on employees. However, it is very important to shape the safety awareness of all employees. Health education and actions based on indirect communication using both the classical media (e.g. educational materials, brochures, leaflets, work safety posters) and electronic (Internet, intranet) are useful instruments in the construction of the awareness of employees and promotion of work safety [24]. Success in solving problems associated with safety is achieved only when employees consciously approach hazards occurring at their workplaces [25].

\section{OBJECTIVE}

The aim of the study is recognition of the opinions of employees of the public forestry sector concerning occupational hazards occurring in their work environment, as well as answer the question which of the selected demographic characteristics of forestry employees are associated with their opinions pertaining to hazards at their workplaces. The adopted goal was achieved based on an anonymous survey conducted in a group of 135 employees of the State Forests.

\section{MATERIALS AND METHOD}

The survey was conducted using an author-constructed questionnaire designed by a team of specialists in ergonomics, $\mathrm{OSH}$, and sociology, within a research project by the University of Life Sciences in Lublin, in cooperation with the Institute of Rural Health and Maria Skłodowska University, also in Lublin. The questionnaire contained items concerning primarily hazards occurring at workplaces in forestry. In addition, it also contained questions pertaining to training courses in $\mathrm{OSH}$, using the $\mathrm{OSH}$ instruction, principles of work safety and occupational hygiene, and activities of $\mathrm{OSH}$ services, as well as respondents' particulars concerning the demographic characteristics of forestry employees (gender, age, total period of employment and period of employment in forestry, position occupied and education). The study was carried out during the period 2017-2018 among employees of the State Forests from the Lublin Province.

The collected material was analyzed using software SPSS 24. Basic descriptive statistics were used - compilations of numbers and percentages of individual variables. Opinions of forestry employees concerning occupational hazards were analyzed from the aspect of independent variables, such as, workplace, period of employment, age and education. The significance of differences in the selected subgroups, according to the above-mentioned variables, was assessed using the chi-square test.

The study included 135 forestry workers employed at the following workplaces: forest ranger - 59 (43.7\%), assistant forest ranger - $54(40.0 \%)$, and office worker - 22 (16.3\%). A half of the respondents (49.6\%) were aged 31-50, while 36 were aged 51 and over, and only 32 employees were aged 18-30. The shortest period of employment in forestry (less than 10 years) was declared by $37 \%$ of respondents, the longest period (more than 21 years) $-43 \%$, while the percentage of those with the period of employment from 11-20 was $20 \%$. Sixty respondents had higher education, 72 - secondary school education, 3 - basic vocational education, whereas no respondents possessed primary school education (Tab. 1).

\section{RESULTS}

The imparting of knowledge concerning work-related hazards to the persons undertaking employment is an important element of the provision of safe conditions at a workplace. The basic source of this knowledge is OSH training organized by the employer. The data obtained show that the majority of the examined forestry employees had participated in compulsory trainings in work safety and occupational hygiene. As many as $93.3 \%$ of the respondents had undergone preliminary general training, $94.8 \%$ - on-site instruction, and 95.6\% periodical training. The occurrence of the situation when an employee does not participate in obligatory OSH trainings is an alarming phenomenon. Based on obtained information, nearly every tenth forestry employee had not participated in compulsory trainings. A considerable percentage of respondents had no training in the provision of first aid nearly $1 / 5$ ( $18.0 \%$ of respondents).

At workplaces in forestry, there occur many hazards the awareness of which among the employees is an important issue in the provision of work safety. The respondents were presented with 13 typical hazards encountered in forestry work, and asked to indicate those which occur at their workplace. From among the risks mentioned (Graph 1), the respondents most often reported risk due to cold climate $(83.7 \%$ of the total number of respondents) and hot

Table 1. Characteristics of the study group.

\begin{tabular}{|c|c|c|c|c|c|c|c|c|c|c|c|}
\hline \multirow[t]{2}{*}{ workplace } & \multicolumn{2}{|c|}{ gender } & \multicolumn{3}{|c|}{ age (years) } & \multicolumn{3}{|c|}{ period of employment in forestry (years) } & \multicolumn{3}{|c|}{ education } \\
\hline & $\mathrm{F}$ & M & $18-30$ & $31-50$ & $51+$ & $<10$ & $11-20$ & $>21$ & $\begin{array}{c}\text { basic } \\
\text { vocational }\end{array}$ & $\begin{array}{c}\text { secondary } \\
\text { school }\end{array}$ & $\begin{array}{l}\text { higher } \\
\text { school }\end{array}$ \\
\hline assistant forest ranger & 3 & 51 & 14 & 35 & 5 & 24 & 15 & 15 & 3 & 35 & 16 \\
\hline office worker & 6 & 16 & 13 & 8 & 1 & 18 & 3 & 1 & 0 & 10 & 12 \\
\hline total & 13 & 112 & 32 & 67 & 36 & 50 & 27 & 58 & 3 & 72 & 60 \\
\hline
\end{tabular}


microclimate (77\%). A high percentage of respondents (74.1\%) perceived biological hazards at their workplace, e.g. contact with bacteria, viruses, fungi, and risk associated with the possibility of contact with wild animals (55.6\%). In addition, a considerable part of the respondents perceived that noise is a source of risk at their work (34.1\%), especially dangerous machines (26.7\%), dust (18.5\%), chemical substances (15.6\%), and forced position at work (14.1\%). Such hazards as excessive physical load (8.9\%), electromagnetic radiation (6.7\%), insufficient lighting at the workplace (5.9\%), and vibration (3\%) were most rarely mentioned (Fig. 1).

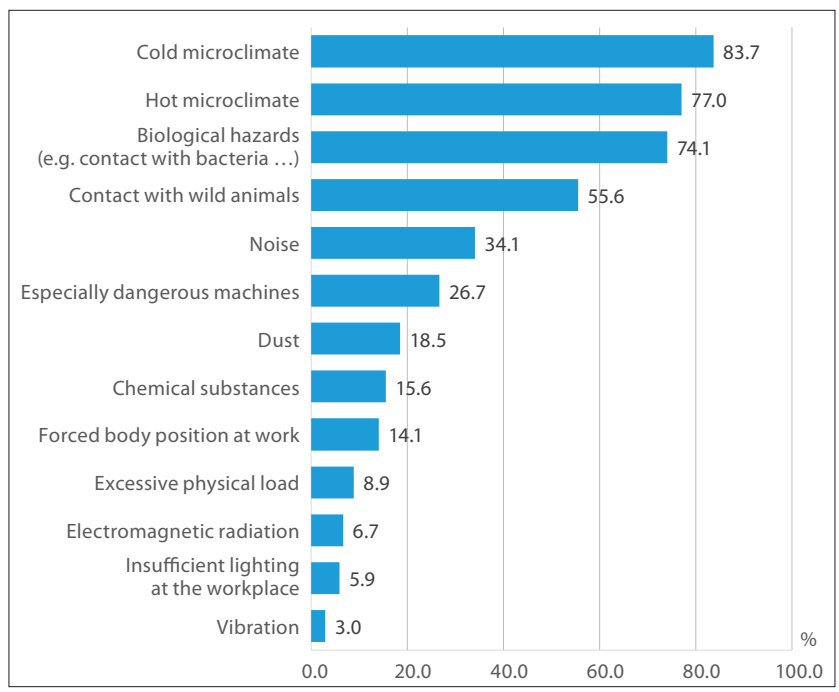

Figure 1. Hazards reported by respondents occurring at their workplaces.

While seeking factors conditioning the perception by forestry employees of hazards at their workplace, a hypothesis was adopted that the way of perceiving these hazards is associated with such respondents' characteristics as: type of workplace, period of employment, age, and education.

The analyses performed showed that the greatest differences in the perception of hazards were observed according to the type of workplace occupied (Tab. 2). Unfavourable effect of cold and hot microclimate was perceived by approx. $90 \%$ of forest rangers and assistant forest rangers, whereas in the group of office employees the risk due to hot climate was indicated by $45.5 \%$ of respondents in this group, while cold climate $-36.4 \%$ (statistically significant differences $\mathrm{p}<0.001)$. These differences certainly result from the fact that forest rangers and assistant forest rangers spend a great amount of working time outdoors, where they are exposed to various weather conditions, depending, e.g. on the season of the year. The perception of risk due to forced body position at work also significantly differed according to the type of workplace. This type of risk was indicated by only approx. 7\% of forest rangers and $11 \%$ of assistant forest rangers, whereas the percentage of office employees who indicated this risk was several times higher ( $40.9 \%$ of respondents in this group) (statistically significant differences $-\mathrm{p}<0.001$ ). Office work is associated with assuming a sitting, often forced body position, which is imposed by the organization of the workplace and type of work performed. When performed in conditions of immobility with long-lasting muscle tension, it results in the development of static load on the musculoskeletal system.

Work at various workplaces is also connected with a different perception of hazards on the part of dangerous machines and biological factors (Tab. 2). The occurrence of risk caused by machines was most often reported by forest rangers (approx. 42.6\%), and to a smaller extent, by forest rangers (approx. 18.6\%), while most rarely by office employees (9.7\%). Significant differences were observed with respect to the perception of biological hazards. This type of risk was indicated by the highest percentage of forest rangers (89.9\%), a considerably lower percentage of forest rangers (64.5\%), and the lowest percentage of office employees (54.5\%). The differences in the way of perceiving hazards caused by machines and biological factors by forest rangers and assistant forest rangers are connected with their performing work outdoors, in direct contact with these hazards.

Slightly lower, but statistically significant differences $(\mathrm{p}<0.05)$ in the way of perceiving hazards by forestry workers employed at various workplaces, were found with respect to such risks as: noise, insufficient lighting at the workplace and contact with wild animals (Tab. 2). Noise, as a risk factor at the workplace, was mentioned by $9.1 \%$ of office employees. This type of risk was indicted by a three times higher percentage of forest rangers $(35.6 \%)$ and a more than four times higher percentage of assistant forest rangers (42.6\%). Risk posed by contact with wild animals was indicated by the majority of assistant forest rangers (64.8\%) and forest rangers (55.9\%), and by a half lower percentage of office employees (approx. $32 \%)$. Some respondents who were employed as forest rangers (13.0\%) considered that insufficient lighting at the workplace is also a risk factor. Only one forest ranger and none of the office employees reported problems associated with lighting.

The perception of hazards at a workplace by the examined forestry employees also differed according to their period of employment (Tab. 2). The greatest differences $(\mathrm{p}<0.001)$ were observed with respect to risk due to hot microclimate. This type of risk was reported by nearly $90 \%$ of respondents who had the longest period of employment of more than 21 years, whereas this risk was perceived by a considerably lower percentage of those who had worked for less than 10 years (66\%) and from 11-20 years (70.4\%). Similar differences were found with respect to cold microclimate $(\mathrm{p}<0.01)$. This risk was indicated by nearly $90 \%$ of respondents with the longest period of employment, and a lower percentage of those with a shorter period of employment: up to 10 years $-78 \%$ of respondents in this group; from $10-20$ years $81.5 \%$ of respondents in this group $(\mathrm{p}<0.01)$. Respondents with a long period of employment reported risk caused by chemical substances at their workplace more often than the remainder. Every fifth respondent (20.7\%) confirmed the presence of chemical risk. An interesting result of analyses was a relatively high percentage of respondents with the shortest period of employment (up to 10 years), who indicated chemical hazards at their workplace (14.0\%), and simultaneously a low percentage of persons who had worked for a relatively long time (11-20 years), who indicated the occurrence of this risk.

The hypothesis adopted concerning the relationship between the way of perceiving hazards at work by forestry employees and their education level was partially confirmed. Two education levels were considered in the analysis lower (basic vocational or secondary school), and higher (Master or licentiate). Statistically significant differences in the evaluations of hazards at workplaces between these groups were observed in the case of risk due to cold climate $(\mathrm{p}<0.01)$, assuming a forced body position $(\mathrm{p}<0.05)$, and 
Table 2. Hazards reported by respondents according to the type of workplace and period of employment.

\begin{tabular}{|c|c|c|c|c|c|c|c|c|}
\hline & \multicolumn{4}{|c|}{ workplace } & \multicolumn{4}{|c|}{ period of employment } \\
\hline & $\begin{array}{c}\text { Forest } \\
\text { ranger } \\
\mathrm{N}=59\end{array}$ & $\begin{array}{c}\text { Assistant } \\
\text { forest ranger } \\
\mathrm{N}=54\end{array}$ & $\begin{array}{c}\text { Office } \\
\text { employees } \\
\mathrm{N}=22\end{array}$ & \multirow[t]{2}{*}{$\begin{array}{c}\text { level of } \\
\text { significance } \\
\text { of differences }\end{array}$} & $\begin{array}{l}\text { up to } 10 \\
\text { years } \\
N=50\end{array}$ & $\begin{array}{l}11-20 \\
\text { years } \\
N=27\end{array}$ & $\begin{array}{c}21 \text { years or } \\
\text { longer } \\
N=58\end{array}$ & \multirow[t]{2}{*}{$\begin{array}{c}\text { level of } \\
\text { significance } \\
\text { of differences }\end{array}$} \\
\hline & \multicolumn{3}{|c|}{$\%$} & & \multicolumn{3}{|c|}{$\%$} & \\
\hline Noise & 35.6 & 42.6 & 9.1 & $\mathrm{p}<0.05$ & 34 & 29.6 & 36.2 & $i_{n}$ \\
\hline Vibration & 1.7 & 5.6 & 0 & $i_{n}$ & 2 & 0 & 5.2 & $i_{n}$ \\
\hline Cold microclimate & 88.1 & 94.4 & 45.5 & $p<0.001$ & 78 & 81.5 & 89.7 & $\mathrm{p}<0.01$ \\
\hline Hot microclimate & 84.7 & 85.2 & 36.4 & $p<0.001$ & 66 & 70.4 & 89.7 & $\mathrm{p}<0.001$ \\
\hline Excessive physical load & 5.1 & 14.8 & 4.5 & $i_{n}$ & 8 & 3.7 & 12.1 & $i_{n}$ \\
\hline Forced body position at work & 6.8 & 11.1 & 40.9 & $\mathrm{p}<0.001$ & 22 & 11.1 & 8.6 & $i_{n}$ \\
\hline Insufficient lighting at workplace & 1.7 & 13 & 0 & $p<0.05$ & 2 & 7.4 & 8.6 & $i_{n}$ \\
\hline Especially dangerous machines & 18.6 & 42.6 & 9.1 & $\mathrm{p}<0.01$ & 26 & 25.9 & 27.6 & $i_{n}$ \\
\hline Chemical substances & 18.6 & 18.5 & 0 & $i_{n}$ & 14 & 7.4 & 20.7 & $i_{n}$ \\
\hline Dust & 15.3 & 24.1 & 13.6 & $i_{n}$ & 22 & 14.8 & 17.2 & $i_{n}$ \\
\hline Biological hazards (e.g. contact with bacteria, viruses, fungi) & 89.8 & 64.8 & 54.5 & $\mathrm{p}<0.01$ & 70 & 74.1 & 77.6 & $i_{n}$ \\
\hline Contact with wild animals & 55.9 & 64.8 & 31.8 & $\mathrm{p}<0.05$ & 60 & 48.1 & 55.2 & $i_{n}$ \\
\hline Electromagnetic radiation & 6.8 & 5.6 & 9.1 & $i_{n}$ & 2 & 14.8 & 6.9 & $i_{n}$ \\
\hline
\end{tabular}

$i_{n}$ - insignificant

Table 3. Hazards reported by respondents according to age and education level.

\begin{tabular}{|c|c|c|c|c|c|c|c|}
\hline & \multicolumn{3}{|c|}{ education } & \multicolumn{4}{|c|}{ age } \\
\hline & Lower & Higher & \multirow{3}{*}{$\begin{array}{c}\text { level of } \\
\text { significance } \\
\text { of differences }\end{array}$} & $18-30$ & $31-50$ & 51 or over & \multirow{3}{*}{$\begin{array}{c}\text { level of } \\
\text { significance } \\
\text { of differences }\end{array}$} \\
\hline & $\mathrm{N}=75$ & $\mathrm{~N}=60$ & & $\mathrm{~N}=32$ & $\mathrm{~N}=67$ & $N=36$ & \\
\hline & \multicolumn{2}{|c|}{$\%$} & & & $\%$ & & \\
\hline Noise & 37.3 & 30 & $i_{n}$ & 25 & 44.8 & 22.2 & $\mathrm{p}<0.05$ \\
\hline Vibration & 2.7 & 3.3 & $i_{n}$ & 0 & 6 & 0 & $i_{n}$ \\
\hline Hot microclimate & 81.3 & 71.7 & $i_{n}$ & 65.6 & 74.6 & 91.7 & $\mathrm{p}<0.05$ \\
\hline Excessive physical load & 10.7 & 6.7 & $i_{n}$ & 6.3 & 13.4 & 2.8 & $i_{n}$ \\
\hline Forced body position at work & 6.7 & 23.3 & $\mathrm{p}<0.05$ & 18.8 & 14.9 & 8.3 & $i_{n}$ \\
\hline Insufficient lighting at the workplace & 4 & 8.3 & $i_{n}$ & 3.1 & 10.4 & 0 & $i_{n}$ \\
\hline Especially dangerous machines & 26.7 & 26.7 & $i_{n}$ & 25 & 31.3 & 19.4 & $i_{n}$ \\
\hline Dust & 16 & 21.7 & $i_{n}$ & 28.1 & 17.9 & 11.1 & $i_{n}$ \\
\hline Biological hazards (e.g. contact with bacteria, viruses, fungi) & 72 & 76.7 & $i_{n}$ & 68.8 & 73.1 & 80.6 & $i_{n}$ \\
\hline Contact with wild animals & 58.7 & 51.7 & $i_{n}$ & 56.3 & 58.2 & 50 & $i_{n}$ \\
\hline Electromagnetic radiation & 1.3 & 13.3 & $p<0.05$ & 0 & 10.4 & 5.6 & $i_{n}$ \\
\hline
\end{tabular}

electromagnetic radiation $(\mathrm{p}<0.05)$. All the hazards were mentioned by a considerably higher percentage of respondents with a higher than a lower education level (Tab. 3). Risk resulting from forced body position at work was mentioned four times more frequently by respondents possessing a higher education level, than those with a lower level. Even greater differences were noted in the case of evaluation of risk caused by electromagnetic radiation $-13.3 \%$ of respondents with higher education level, and $1.3 \%$ of those with a lower education level.

The smallest differences in the perception of hazards at workplaces in forestry were found according to the respondents' age. The significance of differences on the level of $\mathrm{p}<0.05$ was observed for noise and hot microclimate. Noise was most frequently indicated by respondents aged $31-50$ (44.8\%), whereas most rarely by those aged 18-30 (25\%) and those aged over 51 (22.2\%). In turn, hot microclimate was most often reported by employees aged over 51 (more than $91.7 \%)$, and most rarely by those aged $31-50$ (74.6\%) and $18-30(65.6 \%)$.

\section{DISCUSSION}

Work activities during the performance of jobs in forestry are generally characterized by a combination of organizational, environmental, and human factors which exert an effect on the health and safety of forestry employees [26]. 
Based on the study conducted in 2014 by Nowacka and Moskalik on the State Forests National Forest Holding, every year, a similar number of workers is noted who are employed in hazardous conditions. As the risk factors connected with the environment of work and labour were considered, among others: dust, noise, vibration, radiation, cold and hot microclimate, and severe physical effort. Some employees are exposed to several factors at the same time [27].

The presented study shows a high awareness of hazards occurring at workplaces among forestry employees. The hazard most frequently reported by was risk due to cold and hot microclimate. In addition, a high percentage of respondents perceived at their workplace biological hazards and risk associated with the possibility of contact with wild animals.

Data by Statistics Poland demonstrate that the largest number of employees in forestry are exposed at work to mechanical hazards, followed by noise and mechanical vibration [28]. This fact results from consideration in the compilation by the Statistics Poland of the workplaces of lumberjacks, whose work involves the operation of mechanical machines and equipment, which are an important source of noise at work.

The presented study included only forest rangers, assistant forest rangers and office employees, for whom mechanical risk resulting from the operation of machines, noise and mechanical vibration are not the most frequently occurring risk. Nevertheless, 34\% of them mentioned noise risk, and $26.7 \%$ - risk associated with especially dangerous machines. This is due to the fact that a forest ranger and assistant forest ranger, while supervising work activities associated with tree felling, are present within the impact area of exposure of both the noise and specially dangerous machinery used, i.e. for timber extraction. Vibration was most rarely reported by the employees as a risk occurring at their workplace.

The subsequent risk most often indicated by the respondents was biological hazards, which is associated with the performance of work in field conditions, and in direct contact with these hazards to forest rangers and assistant forest rangers. A study conducted by Zielińska-Jankiewicz and Kozajda among three occupational groups (employees of sewage treatment plants and landfill sites, staff of health services and forest services), showed that employees of forest services were the occupational group best informed concerning occupational biological hazards, i.e. tick-borne encephalitis and meningitis, and Lyme disease. However, this knowledge was rather superficial concerning the ticks themselves and, unfortunately, was not translated into knowledge about the microorganisms transmitted by ticks (viruses and bacteria), but may be considered as sufficient in the context of provision of protection against contracting the disease $[20,29]$.

More than $14 \%$ of respondents indicated forced body position as a source of risk at their workplace. It is generally assumed that forced body position is observed when an employee for a long time cannot perform movement other than the repeated one, the position at work is unnatural (forced) for a long time (e.g. kneeling, hands drawn up, lying down, sitting), and the work performed results in loading the same muscles of the employee for a longer time. This results from the occurrence of load and complaints on the part of the musculoskeletal system. A study conducted by Lachowski et al. [13] demonstrated that the majority of employees of the State Forests experienced musculoskeletal disorders, while only $15 \%$ of workers had no such complaints. The employees most often complained of back pain $(71.1 \%$ of respondents in the study), knee pain $(51.3 \%)$, shoulder pain (37.1\%), and neck pain (31.6\%). Approximately $1 / 5$ of respondents also experienced pain in the upper back and in the ankles, elbows and hips.

The human factor exerts an important effect on misbehaviours at work among forestry employees [30]. This primarily concerns incorrect behaviour, neglect, and lack of observance of safety principles. Systematic training of employees, observance of the safety principles, and continuously making them aware of hazards which may occur at work, would allow avoidance of situations threatening human health and life.

\section{CONCLUSIONS}

The presented study is a pilot study; however, in order to form an opinion about awareness and degree of training of forestry employees, studies should be carried out among a more numerous group of respondents, and the questionnaire supplemented with items concerning the organization of work at individual workplaces.

Based on the conducted study concerning work safety and occupational hygiene, and awareness of hazards which may occur at work among forestry employees, it was found that they are aware of risks occurring at their workplace.

The conducted analyses showed that the greatest differences in the way of perceiving risk were observed according to the type of workplace. At the workplaces of a forest ranger and assistant forest ranger, the most frequently reported risk was cold and hot microclimate, which is associated with the site of performing work by these employees, i.e. a forest.

Significant differences in the perception of risk resulting from forced body position were found according to the workplace. The percentage of office employees indicating this risk was several times higher than that among forest rangers and assistant forest rangers.

\section{REFERENCES}

1. http://www.europarl.europa.eu/factsheets/pl/sheet/105/uniaeuropejska-i-obszary-lesne. (access: 01.04.2019). (in Polish).

2. Rocznik statystyczny leśnictwa 2018. Główny Urząd Statystyczny, Warszawa 2018. ISSN 2657-3199. https://stat.gov.pl/obszarytematyczne/roczniki-statystyczne/roczniki-statystyczne/rocznikstatystyczny-lesnictwa-2018,13,1.html. (access: 27.03.2019).

3. Lasy Państwowe w liczbach 2018. Wydawca: Centrum Informacyjne Lasów Państwowych, Warszawa. ISBN 978-83-65659-39-2. http:// www.lasy.gov.pl/pl/informacje/publikacje/do-poczytania/lasypanstwowe-w-liczbach-1/lasy-panstwowe-w-liczbach-2018.pdf (access: 27.03.2019) (in Polish).

4. Nowacka W. Zagrożenia w leśnictwie i ich negatywne konsekwencje. Promotor BHP 2013; 4: 44-46. (in Polish)

5. Nowacka W, Moskalik T. Negatywne skutki pracy w leśnictwie ze szczególnym uwzględnieniem pozyskiwania drewna. Poznańskie Towarzystwo Przyjaciół Nauk. Wydział Nauk Rolniczych i Leśnych. Forestry Letters. 2013; 105: 85-93. (in Polish).

6. Cheta M, Marcu MV, Borz SA. Workload, Exposure to Noise, and Risk of Musculoskeletal Disorders: A Case Study of Motor-Manual Tree Feeling and Processing in Poplar Clear Cuts. Forests. 2018; 9: 300; doi:10.3390/f9060300

7. Fonseca A, Aghazadeh F, de Hoop C, Ikuma L, Al-Qaisi S. Effect of noise emitted by forestry equipment on workers' hearing capacity. Int J Ind Ergon. 2015; 46: 105-112. 
8. Poje A, Spinelli R, Magagnotti N, Mihelic M. Exposure to noise in wood chipping operations under the conditions of agro-forestry. Int J Ind Ergon. 2015; 50: 151-157.

9. Gembalska-Kwiecień A. Wpływ warunków pracy na błędne działanie pracownika. Bezp Pr Nauka Tech. 2013; 4: 18-21. (in Polish).

10. Grzywiński W, Sawa L, Nowik A, Nowicki G. Struktura wypadków przy pracy w Regionalnej dyrekcji Lasów Państwowych w Szczecinku w latach 1990-2009. Sylwan 2013; 157(6): 403-411. (in Polish)

11. Grzywiński W, Wandycz A. Technika pracy jako prewencja dolegliwości mięśniowo-szkieletowych u drwali. In: Paluch R, Jach K, Michalski R. (eds). Obciążenie układu ruchu. Przyczyny i skutki. Polska Akademia Nauk - Komitet Ergonomii, Wrocław 2006, s. 69-75. (in Polish)

12. Choina P, Solecki L, Goździewska M, Buczaj A. Assessment of musculoskeletal system pain complaints reported by forestry workers. Ann Agric Environ Med. 2018; 25(2): 338-344. doi: 10.26444/ aaem/86690

13. Lachowski S, Choina P, Florek-Łuszczki M, Goździewska M, Jezior J. Dissatisfaction with work as a risk factor of musculoskeletal complaints among foresters in Poland. Ann Agric Environ Med. 2017; 24(4): 706711. doi: 10.26444/aaem/80985. Epub 2017 Dec 15

14. Grzywiński W, Tomczak A, Jelonek T, Skonieczna J, Jakubowski M. Obciążenie pracą na stanowiskach leśniczego i podleśniczego. Streszczenia konferencyjne. Konferencja katedr jednoimiennych, Znaczenie użytkowania lasu w gospodarce leśnej XXI wieku. Uniwersytet Przyrodniczy w Poznaniu, 2016, s. 12 (in Polish).

15. Kowalska M, Bugajska J. Problemy zdrowotne osób pracujących z komputerem. (Health problems among computer workers). Med $\mathrm{Pr}$. 2009; 60(4): 321-325. (in Polish)

16. Stojek NM. Ocena ryzyka zagrożenia czynnikami biologicznymi w miejscu pracy rolnika i leśnika. Ocena ryzyka zawodowego w rolnictwie. Lublin 2010: 79- 86 (in Polish).

17. De Keukeleire M, Robert A, Luyasu V, Kabamba B, Vanwambeke SO. Seroprevalence of Borrelia burgdorferi in Belgian forestry workers and associated risk factors. Parasit Vectors. 2018; 11(1): 277. doi:10.1186/ s13071-018-2860-2.

18. Zákutná L, Dorko E, Mattová E, Rimárová K. Sero-epidemiological study of Lyme disease among high-risk population groups in eastern Slovakia. Ann Agric Environ Med. 2015; 22: 632-636. doi: $10.5604 / 12321966.1185765$.

19. Jurke A, Bannert N, Brehm K, Fingerle V, Kempf VAJ, Kömpf D, et al. Serological survey of Bartonella spp., Borrelia burgdorferi, Brucella spp., Coxiella burnetii, Francisella tularensis, Leptospira spp., Echinococcus,
Hanta-, TBE- and XMR-virus infection in employees of two forestry enterprises in North Rhine-Westphalia, Germany, 2011-2013. Int J Med Microbiol. 2015; 305: 652-662. doi: 10.1016/j.ijmm.2015.08.015

20. Zielińska-Jankiewicz K, Kozajda A. Wiedza wybranych grup zawodowych o rodzajach czynników biologicznych obecnych w środowisku pracy oraz o sposobach ochrony przed ich szkodliwym wpływem. Med Pr. 2003; 54(5): 399-406 (in Polish).

21. Rigaud E, Jaulhac B, Garcia-Bonnet N, Hunfeld KP, Féménia F, Huet $\mathrm{D}$, et al. Seroprevalence of seven pathogens transmitted by the Ixodes ricinus tick in forestry workers in France. Clin Microbiol Infect. 2016; 22: 735. e1-735.e9. doi: 10.1016/j.cmi.2016.05.014.

22. Kiewra D, Szymanowski M, Zalewska G, Dobracka B, Dobracki W, Klakočar J, Czułowska A, Plewa-Tutaj K. Seroprevalence of Borrelia burgdorferi in forest workers from inspectorates with different forest types in Lower Silesia, SW Poland: preliminary study. Int J Environ Health Res. 2018; 28(5): 502-510. doi: 10.1080/09603123.2018.1489954.

23. Grzywiński W, Kapelan A, Wiekiera J. Analysis of accident rate in the Regional Directorate of the State Forests in Poznan in the years 1995-2007. In: Sowa JM, Barszcz A, Szewczyk G [red.]. Technology and ergonomics in the service of modern forestry. Wyd. UR w Krakowie, $2011 ; 55-71$.

24. Dutkiewicz J, Cisak E, Wójcik-Fatla A, Zając V, Sroka J. Profilaktyka chorób odkleszczowych. Bezp Pr Nauka Tech. 2014; 4: 22-24. (in Polish)

25. Pawlak H, Maksym P, Pecyna A. Analysis of awareness concerning the occupational health and safety of food sector employees. Inż Rol. 2014; 3(151): 129-137. Doi: 10.14654/ir.2014.151.065.

26. Lilley R, Feyer AM, Kirk P, Gander P. A survey of forest workers in New Zealand - Do hours of work, rest, and recovery play a role in accidents and injury? J Saf Res. 2002; 33: 53-71.

27. Nowacka W, Moskalik T. Działania w zakresie profilaktyki negatywnych skutków pracy w leśnictwie. Studium przypadków w Państwowym Gospodarstwie Leśnym Lasy Państwowe. Studia i Materiały CEPL w Rogowie, 2014; 39/2B/2014 (in Polish).

28. https://stat.gov.pl/obszary-tematyczne/rolnictwo-lesnictwo/lesnictwo/ lesnictwo-2017,1,13.html. (access: 30.11.2018)

29. Kozajda A, Zielińska-Jankiewicz K, Szadkowska-Stańczyk I. Wiedza wybranych grup zawodowych o rodzajach czynników biologicznych obecnych w środowisku pracy oraz o sposobach ochrony przed ich szkodliwym wpływem. Część II. Med Pr. 2005; 57(3): 205-211.

30. Melemez K. Risk factor analysis of fatal forest harvesting accidents: A case study in Turkey. Saf Sci. 2015; 79: 369-378.

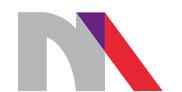

\section{Ministry of Science and Higher Education}

Republic of Poland

Generation of the DOI (Digital Object Identifier) - task financed under the agreement No. 618/P-DUN/2019 by the Minister of Science and Higher Education 